\title{
Growth of the pearl oyster Pteria sterna under different thermic and feeding conditions
}

\author{
Miguel A. del Río-Portilla, Ana D. Re-Araujo, Domenico Voltolina \\ Departamento de Acuicultura, Centro de Investigación Científica y de Educación Superior de Ensenada, AP 2732. \\ 22800 Ensenada, Baja California, México
}

\begin{abstract}
The combined influence of temperature and food concentration on Pteria sterna growth was determined, using 3 temperatures and 3 food concentrations. During $15 \mathrm{wk}$, the shell was measured weekly along the axis of maximum growth. The 2 higher growth rates $\left(4.8\right.$ and $\left.4.2 \mathrm{~mm} \mathrm{mo}^{-1}\right)$ were obtained with the highest ration, at 30 and $25^{\circ} \mathrm{C}$, while with the lowest food concentration growth was not temperature dependent. By the response surface analysis, a synergistic effect of temperature and food concentration on growth was found. Food concentration, but not temperature, had an important influence on condition index (ash free meat dry weight/shell dry weight $\times 100$ ).
\end{abstract}

\section{INTRODUCTION}

Restocking natural beds with natural or laboratoryproduced juveniles has been suggested by various authors if a natural resource is exploited above the level of natural recruitment (e.g. Espina 1989 for Tivela stultorum and Hahn 1989 and literature therein for Haliotis spp., Trochus niloticus and Strombus gigas). This is the case for the pearl oyster Ptena sterna Gould, which is considered an endangered species in Mexico (Baqueiro 1987), in spite of a permanent ban on harvesting enacted by the Mexican government in 1939. Studies in proximity of some of the known natural beds of this mollusk have revealed that spat settlement is scarce (Bückle-Ramírez et al. 1992) due to the low numbers of larvae competent for settling in the plankton of those areas (Serrano-Guzmán 1992). For this reason, it has been proposed that laboratoryproduced juveniles be used for restocking purposes as well as for aquacultural activities (Baqueiro 1987. Araya-Nuñez 1988, Bückle-Ramírez et al. 1992).

The juveniles used for these purposes should be in good physiological condition, in order to withstand the stress of the change from the laboratory to the natural environment. Further, acclimation should be done when water conditions are close to optimum for body growth, in order to ameliorate the possibility of survival to subsequent adverse conditions. The literature available on Pteria sterna growth is based on field observations (Aguirre-Hinojosa 1987, Singh-Cabanillas 1990, Bückie-Ramírez et al. 1992) showing high growth rates during summer months, with notably lower values in winter. However, since food availability is at its lowest during colder months (SerranoGuzmán 1992), these observations are not sufficient to determine the relative importance of temperature and food availability for $P$. sterna growth.

The aim of the present work was to study in the laboratory how these factors influence both shell and body growth. It also considers the limits within which their interactions have the best effects in laboratory conditions and conversely if, outside these limits, either factor might cease to be effective, or even have a negative effect on body growth, as evaluated from the organisms' condition index.

\section{MATERIALS AND METHODS}

Specimens of between 5 and $10 \mathrm{~mm}$ shell height were collected on July 4-5, 1990, from spat collectors after 2 mo of immersion in 'La Gringa' cove located in Bahia de Los Angeles $\left(113^{\circ} \mathrm{W}, 28^{\circ} \mathrm{N}\right)$. They were separated from the substrate with a scalpel, held for 24 to $48 \mathrm{~h}$ in an ice box at ca $27^{\circ} \mathrm{C}$, and subsequently transported to the laboratory where they were maintained in 
an aquarium of capacity $45 \mathrm{I}$ and fed ad libitum twice daily for 8 wk with Chaetoceros sp. (clone $\mathrm{CH}-\mathrm{X}-1$ from the collection of Centro de Investigación Científica y de Educación Superior de Ensenada; VoltolinaLobina et al. 1991). This was chosen in preference to other microalgae used in aquaculture for the following reasons: (1) Good results have been obtained with this strain for various filter-feeders such as the mussels Mytilus edulis, $M$. galloprovincialis and Modiolus capax, the oyster Crassostrea gigas and several peneid and brine shrimps (Voltolina-Lobina et al. 1991). (2) Unicellular Chaetoceros spp., such as the one used, are common and abundant worldwide in coastal areas, and several strains have been isolated in Baja California coastal waters (López-Elías pers. comm.). (3) The genus Chaetoceros has been mentioned as one of the common constituents of Bahia de Los Angeles phytoplankton communities (Ayala-Sánchez \& Michel 1980).

Chaetoceros sp. was also used for the experimental phase, using different semi-continuous cultures with f/2 medium (Guillard \& Ryther 1962) at daily dilution rates of between 50 and $33 \%$ for the 18 and $400 \mathrm{l}$ cultures respectively.

The 9 experimental aquaria were divided into groups of 3 , each kept in a constant temperature water bath at either 20,25 or $30^{\circ} \mathrm{C}$. Each aquarium was subdivided with acrylic walls into 3 sections, to allow the experiment to be run in triplicate. Each aquarium received all 3 diets, 1 per section predetermined at random.

The size ration and the feeding frequency were based on observations made during the acclimation period. It was decided that the maximum ration allowable was, for a twice daily feeding routine, ca $8 \%$ of the meat dry weight, after which pseudofaeces began to be produced. The other rations were 50 and $25 \%$ of the highest allowable value, resulting in 8,4 and $2 \%$ of meat dry weight.

After verifying the normality of the size distribution by chi-square goodness of fit test ( $\alpha=0.05), 9$ juveniles were stocked into each section of the experimental aquaria. By 2-way ANOVA, it was also shown that size distributions were homogeneous $(\alpha=0.05)$.

Temperature was measured twice daily and dissolved oxygen, $\mathrm{pH}$ and salinity every $24 \mathrm{~h}$. These were kept approximately constant by frequent water changes. The aquaria were cleaned every second day with UV-sterilized filtered sea water.

The food rations were calculated on the basis of the equation $\mathrm{DW}=0.00869 \mathrm{AMG}$, where $\mathrm{DW}=$ oyster dry weight ( $\mathrm{mg}$ ); and $\mathrm{AMG}=$ radius along the axis of maximum growth (cm) (Bückle-Ramírez et al. 1992). The volume of culture necessary was determined by the microalgal density, their average dry weight $(30 \mu \mathrm{g}$ per $10^{6}$ cells; López-Elías 1990) and the calculated dry weight of Pteria sterna. Care was taken to start each feeding with the same microalgal density $(20,40$ and $80 \times 10^{3}$ cells $\mathrm{ml}^{-1}$ ) by modifying the volume of water added to the aquarium.

The experiment lasted $15 \mathrm{wk}$ (31 August to 14 December). The initial dry weight and condition index were obtained using 20 organisms from the original population. The experimental design consisted of 3 temperatures $\left(20,25\right.$ and $\left.30^{\circ} \mathrm{C}\right)$ simulating the thermal range of the original environment between May and November (Aguirre-Hinojosa 1987) and 3 food rations (2, 4 and $8 \%$ of meat dry weight). AMG was measured once a week (mm). Growth with different treatments was compared with analysis of covariance and StudentNewman-Keuls (SNK) tests (Zar 1974, Steel \& Torrie 1988)

After $15 \mathrm{wk}$, the organisms were starved for $24 \mathrm{~h}$, measured and weighed (total wet weight; wet and dry weights of shell; wet, dry and ash weights of the meat) by drying the shell and the meat at $60^{\circ} \mathrm{C}$ for 2 and $24 \mathrm{~h}$ respectively, and ashing the meat at $590^{\circ} \mathrm{C}$ for $12 \mathrm{~h}$. The condition index was estimated using the equation DWM $/$ DWS $\times 100$ where DWM = ash-free meat dry weight and WDS = shell dry weight (Lucas \& Beninger 1985)

Response surface analysis is a technique used to describe in a bi-dimensional form the relative importance of the experimental factors and their interactions on a given biological process (Alderdice 1972, Lough \& Gonor 1973a, b). It consists of generating a function, usually quadratic since this generally allows an optimum interpretive response (Schnute \& McKinnell 1984), which relates experimental conditions (factors) to biological responses. The technique involves the use of stepwise multiple regression (Zar 1974) to obtain the best model and the percentage of the total variance explained by the model itself.

In order to compare growth in the laboratory and in the field, 110 organisms of the original batch were kept in 2 Nestier cages at the collection site.

\section{RESULTS}

Temperature, salinity, oxygen saturation and $\mathrm{pH}$ did not vary widely (Table 1), and it was therefore concluded that their effects on growth were similar and that they did not affect survival, which was high in all cases (Table 2).

Since no differences were found among the 3 replicates of each treatments ( 1 -way ANOVA; $\alpha=0.05$ ) the data were pooled for statistical analysis. The initial mean size ranged between 11.3 and $12.3 \mathrm{~mm}$ (overall mean $11.7 \mathrm{~mm}$ ), and the final mean size of each group depended on the treatments. The growth curves of 
Table 1. Physical and chemical variables (mean and SD) for the 9 treatments. Temperature was measured twice a day, other variables once a day

\begin{tabular}{|c|c|c|c|c|c|c|c|c|c|}
\hline \multirow{2}{*}{$\begin{array}{l}\text { Temperature: } \\
\text { Food: }\end{array}$} & \multicolumn{3}{|c|}{$20^{\circ} \mathrm{C}$} & \multicolumn{3}{|c|}{$25^{\circ} \mathrm{C}$} & \multicolumn{3}{|c|}{$30^{\circ} \mathrm{C}$} \\
\hline & $2 \%$ & $4 \%$ & $8 \%$ & $2 \%$ & $4 \%$ & $8 \%$ & $2 \%$ & $4 \%$ & $8 \%$ \\
\hline Temperature $\left({ }^{\circ} \mathrm{C}\right)$ & $\begin{array}{l}19.84 \\
(0.38)\end{array}$ & $\begin{array}{l}19.86 \\
(0.36)\end{array}$ & $\begin{array}{l}19.86 \\
(0.36)\end{array}$ & $\begin{array}{l}25.00 \\
(0.50)\end{array}$ & $\begin{array}{l}25.01 \\
(0.51)\end{array}$ & $\begin{array}{l}24.96 \\
(0.46)\end{array}$ & $\begin{array}{l}29.85 \\
(0.82)\end{array}$ & $\begin{array}{l}29.78 \\
(0.87)\end{array}$ & $\begin{array}{l}29.81 \\
(0.83)\end{array}$ \\
\hline Salinity $(\%)$ & $\begin{array}{l}32.45 \\
(1.93)\end{array}$ & $\begin{array}{l}32.45 \\
(1.99)\end{array}$ & $\begin{array}{l}32.60 \\
(1.85)\end{array}$ & $\begin{array}{l}33.06 \\
(2.23)\end{array}$ & $\begin{array}{l}32.94 \\
(2.18)\end{array}$ & $\begin{array}{l}33.31 \\
(2.03)\end{array}$ & $\begin{array}{l}32.15 \\
(2.78)\end{array}$ & $\begin{array}{l}32.15 \\
(2.73)\end{array}$ & $\begin{array}{l}32.33 \\
(2.69)\end{array}$ \\
\hline Oxygen $(\%)$ & $\begin{array}{l}95.02 \\
(3.20)\end{array}$ & $\begin{array}{l}95.04 \\
(2.63)\end{array}$ & $\begin{array}{l}94.77 \\
(2.96)\end{array}$ & $\begin{array}{l}95.42 \\
(2.56)\end{array}$ & $\begin{array}{l}95.12 \\
(2.52)\end{array}$ & $\begin{array}{l}94.55 \\
(3.07)\end{array}$ & $\begin{array}{l}93.46 \\
(3.57)\end{array}$ & $\begin{array}{l}92.81 \\
(4.13)\end{array}$ & $\begin{array}{l}91.64 \\
(6.49)\end{array}$ \\
\hline $\mathrm{pH}$ & $\begin{array}{c}8.03 \\
(0.12)\end{array}$ & $\begin{array}{c}8.00 \\
(0.13)\end{array}$ & $\begin{array}{c}7.97 \\
(0.12)\end{array}$ & $\begin{array}{c}8.07 \\
(0.19)\end{array}$ & $\begin{array}{c}8.02 \\
(0.20)\end{array}$ & $\begin{array}{c}8.02 \\
(0.20)\end{array}$ & $\begin{array}{c}8.06 \\
(0.14)\end{array}$ & $\begin{array}{c}8.02 \\
(0.15)\end{array}$ & $\begin{array}{l}7.95 \\
(0.18)\end{array}$ \\
\hline
\end{tabular}

Table 2. Pteria sterna. General data (mean and SD) from the growth experiment. Superscript letters indicate growth rates not significantly different from one another (obtained by covariance analysis and Student-Newman-Keuls test, $\alpha=0.05$ ). AMG: radius along axis of maximum growth. Total no. of oysters was 28

\begin{tabular}{|c|c|c|c|c|c|c|c|c|c|}
\hline \multirow{2}{*}{$\begin{array}{l}\text { Temperature: } \\
\text { Food: }\end{array}$} & \multicolumn{3}{|c|}{$20^{\circ} \mathrm{C}$} & \multicolumn{3}{|c|}{$25^{\circ} \mathrm{C}$} & \multicolumn{3}{|c|}{$30^{\circ} \mathrm{C}$} \\
\hline & $2 \%$ & $4 \%$ & $8 \%$ & $2 \%$ & $4 \%$ & $8 \%$ & $2 \%$ & $4 \%$ & $8 \%$ \\
\hline Mortality $(\%)$ & 0.0 & 3.7 & 0.0 & 3.7 & 3.7 & 0.0 & 7.4 & 3.7 & 0.0 \\
\hline Initial AMG (mm) & $\begin{array}{l}11.7 \\
(1.9)\end{array}$ & $\begin{array}{l}11.9 \\
(2.0)\end{array}$ & $\begin{array}{l}11.8 \\
(1.6)\end{array}$ & $\begin{array}{l}11.3 \\
(1.6)\end{array}$ & $\begin{array}{l}11.4 \\
(2.1)\end{array}$ & $\begin{array}{l}11.4 \\
(2.4)\end{array}$ & $\begin{array}{l}11.7 \\
(2.0)\end{array}$ & $\begin{array}{l}11.9 \\
(1.9)\end{array}$ & $\begin{array}{l}12.3 \\
(2.1)\end{array}$ \\
\hline Final AMG (mm) & $\begin{array}{l}17.4 \\
(2.8)\end{array}$ & $\begin{array}{l}20.2 \\
(3.6)\end{array}$ & $\begin{array}{l}21.0 \\
(3.8)\end{array}$ & $\begin{array}{l}17.6 \\
(2.2)\end{array}$ & $\begin{array}{l}22.9 \\
(3.8)\end{array}$ & $\begin{array}{l}26.2 \\
(4.9)\end{array}$ & $\begin{array}{l}17.8 \\
(2.7)\end{array}$ & $\begin{array}{l}23.9 \\
(2.7)\end{array}$ & $\begin{array}{l}29.2 \\
(3.9)\end{array}$ \\
\hline Growth $\left(\mathrm{mm} \mathrm{wk}^{-1}\right)$ & $0.4^{\mathrm{d}}$ & $0.6^{\mathrm{ab}}$ & $0.6^{\mathrm{bc}}$ & $0.4^{\mathrm{ab}}$ & $0.8^{c}$ & $1.0^{\mathrm{d}}$ & $0.4^{\mathrm{ab}}$ & $0.8^{c}$ & $1.1^{d}$ \\
\hline \multicolumn{10}{|l|}{ Weight } \\
\hline Meat (\%) & $\begin{array}{l}21.8 \\
(1.8)\end{array}$ & $\begin{array}{l}26.0 \\
(4.2)\end{array}$ & $\begin{array}{l}28.6 \\
(3.1)\end{array}$ & $\begin{array}{l}20.6 \\
(2.1)\end{array}$ & $\begin{array}{l}26.3 \\
(1.4)\end{array}$ & $\begin{array}{l}33.8 \\
(2.1)\end{array}$ & $\begin{array}{l}24.0 \\
(3.7)\end{array}$ & $\begin{array}{l}25.2 \\
(2.0)\end{array}$ & $\begin{array}{l}31.5 \\
(1.4)\end{array}$ \\
\hline Dry meat $(\%)$ & $\begin{array}{l}20.1 \\
(1.8)\end{array}$ & $\begin{array}{l}21.2 \\
(4.2)\end{array}$ & $\begin{array}{l}23.4 \\
(3.1)\end{array}$ & $\begin{array}{l}18.0 \\
(2.1)\end{array}$ & $\begin{array}{l}16.6 \\
(1.4)\end{array}$ & $\begin{array}{l}21.1 \\
(2.1)\end{array}$ & $\begin{array}{l}15.6 \\
(3.7)\end{array}$ & $\begin{array}{l}17.5 \\
(2.0)\end{array}$ & $\begin{array}{l}19.9 \\
(1.4)\end{array}$ \\
\hline Organic weight $(\%)$ & $\begin{array}{l}81.5 \\
(3.4)\end{array}$ & $\begin{array}{l}82.6 \\
(6.5)\end{array}$ & $\begin{array}{l}86.1 \\
(5.0)\end{array}$ & $\begin{array}{l}77.8 \\
(1.6)\end{array}$ & $\begin{array}{l}78.4 \\
(2.8)\end{array}$ & $\begin{array}{l}84.8 \\
(4.0)\end{array}$ & $\begin{array}{l}73.7 \\
(5.7)\end{array}$ & $\begin{array}{l}79.8 \\
(2.2)\end{array}$ & $\begin{array}{l}85.1 \\
(1.7)\end{array}$ \\
\hline Shell (\%) & $\begin{array}{l}73.5 \\
(0.1)\end{array}$ & $\begin{array}{l}69.6 \\
(5.2)\end{array}$ & $\begin{array}{l}66.7 \\
(4.0)\end{array}$ & $\begin{array}{l}72.1 \\
(5.0)\end{array}$ & $\begin{array}{l}68.0 \\
(3.5)\end{array}$ & $\begin{array}{l}60.9 \\
(5.6)\end{array}$ & $\begin{array}{l}71.6 \\
(4.1)\end{array}$ & $\begin{array}{l}70.0 \\
(6.7)\end{array}$ & $\begin{array}{l}63.5 \\
(3.5)\end{array}$ \\
\hline Dry shell (\%) & $\begin{array}{l}78.2 \\
(1.9)\end{array}$ & $\begin{array}{l}74.0 \\
(2.6)\end{array}$ & $\begin{array}{l}71.4 \\
(3.2)\end{array}$ & $\begin{array}{l}79.5 \\
(3.9)\end{array}$ & $\begin{array}{l}73.7 \\
(4.6)\end{array}$ & $\begin{array}{l}66.2 \\
(3.7)\end{array}$ & $\begin{array}{l}76.0 \\
(3.8)\end{array}$ & $\begin{array}{l}74.8 \\
(12.7)\end{array}$ & $\begin{array}{l}68.5 \\
(2.9)\end{array}$ \\
\hline Conversion rate $(\%)$ & 13.5 & 23.5 & 19.7 & 5.0 & 22.0 & 27.8 & 0.7 & 15.3 & 21.0 \\
\hline Condition Index & $\begin{array}{c}52.5 \\
(12.3)\end{array}$ & $\begin{array}{l}70.9 \\
(21.1)\end{array}$ & $\begin{array}{l}100.4 \\
(32.0)\end{array}$ & $\begin{array}{l}43.3 \\
(9.6)\end{array}$ & $\begin{array}{l}60.4 \\
(10.3)\end{array}$ & $\begin{array}{l}118.2 \\
(35.2)\end{array}$ & $\begin{array}{l}39.6 \\
(9.7)\end{array}$ & $\begin{array}{c}58.0 \\
(13.7)\end{array}$ & $\begin{array}{c}97.2 \\
(18.8)\end{array}$ \\
\hline
\end{tabular}

juveniles throughout the experiment were nearly linear (Fig. 1). Covariance analysis showed a slope difference among treatments related to both variables and to their interaction, with significantly higher growth for the treatments at $30^{\circ} \mathrm{C}, 8 \%$ and $25^{\circ} \mathrm{C}, 8 \%$ and lower values for all other treatments of high temperature and high or intermediate food concentrations (Table 2). The lowest growth rates were those of $2 \%$ ration, irrespective of temperature. The growth for the $30{ }^{\circ} \mathrm{C}$ and $8 \%$ treatment was 2.75 times higher than the $2 \%$ treatments.

In order to determine the linear and quadratic effects of temperature $\left(T, T^{2}\right)$, and food ration $\left(A, A^{2}\right)$ and of their interaction $(T \times A)$, multiple regression analysis was applied to growth rates $\left(C, \mathrm{~mm} \mathrm{wk}^{-1}\right)$. Statistical analysis (Table 3 ) shows that all variables were significantly important $(p<0.05)$ with the exception of the linear effect of food, and that the most important effects were those of the interaction and of the square power of food. The polynomial obtained:

$$
\begin{aligned}
C= & -1.4736+0.1401 T-0.0031 T^{2} \\
& -0.0142 A^{2}+0.0090 T \times A
\end{aligned}
$$

explained $93 \%$ of the observed variance. The response surface clearly shows the interaction between food concentration and temperature (Fig. 2). 


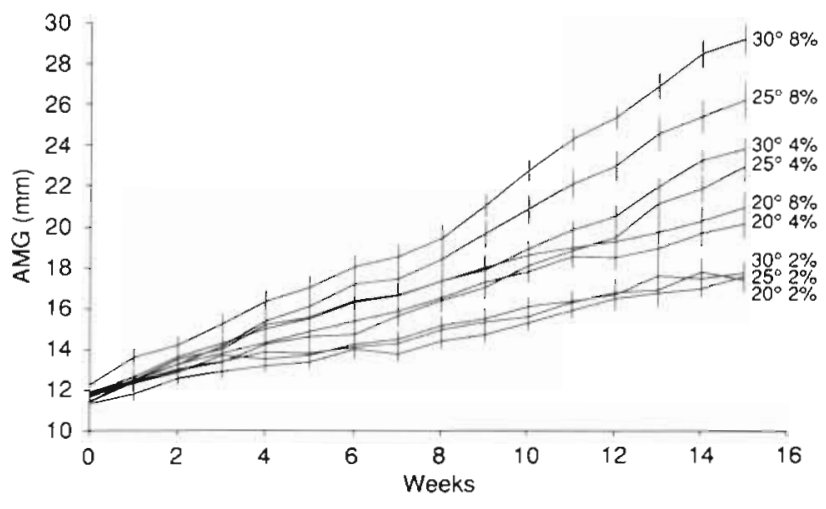

Fig. 1. Pteria sterna. Growth under different temperatures $\left(20,25,30^{\circ} \mathrm{C}\right)$ and feeding regimes $(2,4$ and $8 \%$ of meat dry weight). AMG: radius (mm, mean $\pm 1 \mathrm{SE}$ ) along axis of maximum growth

Meat content varied between 20.6 to $31.5 \%$ of the total wet weight and the organic content of meat from 73.7 to $86.1 \%$; both showed a tendency to increase in a direct relation to food concentration and an inverse relation to temperature (Table 2). At low food concentrations, the daily rate of food conversion was inversely related to temperature, and for the highest concentration, the maximum was at $25^{\circ} \mathrm{C}$.

The model for the Condition Index (CI), that included the effects of all variables (linear, quadratic and interaction), explained only ca $60 \%$ of the total vari- ance observed, with low probabilities (Table 4). The model was simplified by stepwise multiple regression. to include only $A+T^{2}$; it explained the same percentage of the total variance but with high probabilities The resulting polynomial was:

$$
\mathrm{CI}=36.862-0.020 T^{2}+10.089 \mathrm{~A}
$$

The response surface shows the strong effect of food concentration (Fig. 3)

Pteria sterna juveniles kept in Bahia de Los Angeles grew better than the lab-cultured organisms. From an initial mean ( $\pm \mathrm{SD}$ ) AMG in July of $7.35 \pm 1.78 \mathrm{~mm}$, the specimens grew to $30.7 \pm 4.60 \mathrm{~mm}$ by November and $38.7 \pm 8.25 \mathrm{~mm}$ by January 1991. Condition indexes were similar, but more variable under natural conditions than in the laboratory: $81.09 \pm 17.47$ and $106.95 \pm$ $41.96 \mathrm{~mm}$, for November and January respectively.

\section{DISCUSSION}

The response surfaces (Figs. $2 \& 3$ ) indicate that our experimental conditions did not reach an optimum for growth and condition index. Temperature had a direct influence on growth with high food concentrations, but its increase caused a lower condition index, probably because of the higher energy requirement of the organisms at high temperatures (Bayne 1973, Widdows 1978), and not through its effect on filtration rate. This

Table 3. Pteria sterna. Square model evaluation of growth $\left(\mathrm{mm} \mathrm{wk}^{-1}\right)$. T: temperature, $A$ : food ration

\begin{tabular}{|lrrrrr|}
\hline Independent variable & Coefficient & $\mathrm{SE}$ & $\mathrm{R}^{2}(\%)$ & $t$ & $\mathrm{p}$ \\
\hline$T \times A$ & 0.008 & 0.001 & 79.40 & 6.215 & 0.000 \\
$A^{2}$ & -0.017 & 0.004 & 88.96 & -4.709 & 0.000 \\
$T^{2}$ & -0.003 & 0.001 & 91.48 & -2.766 & 0.012 \\
$T$ & 0.144 & 0.057 & 93.02 & 2.531 & 0.019 \\
$A$ & 0.050 & 0.050 & 93.03 & 1.016 & 0.321 \\
Constant & -1.633 & 0.714 & & -2.288 & 0.033 \\
\hline
\end{tabular}

Table 4. Pteria sterna. Square and simplified model evaluation of condition index (CI). Variables as in Table 3

\begin{tabular}{|c|c|c|c|c|c|}
\hline Independent variable & Coefficient & $\mathrm{SE}$ & $\mathrm{R}^{2}(\%)$ & $t$ & $\mathrm{p}$ \\
\hline \multicolumn{6}{|l|}{ Square model } \\
\hline$A$ & 3.107 & 5.024 & 58.45 & 0.619 & 0.537 \\
\hline$T^{2}$ & -0.178 & 0.115 & 59.81 & -1.545 & 0.127 \\
\hline$T \times A$ & 0.174 & 0.132 & 59.97 & 1.321 & 0.188 \\
\hline$T$ & 7.099 & 5.790 & 60.08 & 1.226 & 0.221 \\
\hline$A^{2}$ & 0.255 & 0.368 & 59.99 & 0.692 & 0.490 \\
\hline Constant & -34.199 & 72.395 & & -0.472 & 0.637 \\
\hline \multicolumn{6}{|l|}{ Simplified model } \\
\hline A & 10.089 & 0.541 & 58.45 & 18.643 & 0.000 \\
\hline$T^{2}$ & -0.020 & 0.007 & 59.81 & -2.998 & 0.003 \\
\hline Constant & 36.862 & 5.106 & & 7.220 & 0.000 \\
\hline
\end{tabular}




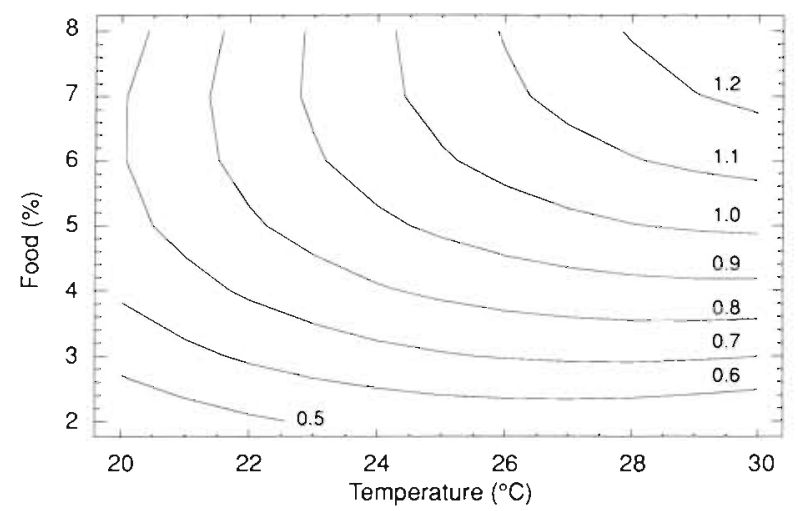

Fig. 2. Pteria sterna. Growth response $\left(\mathrm{mm} \mathrm{wk}^{-1}\right.$, measured along axis of maximum growth) for temperatures 20 to $30^{\circ} \mathrm{C}$ and food rations 2 to $8 \%$ of meat dry weight

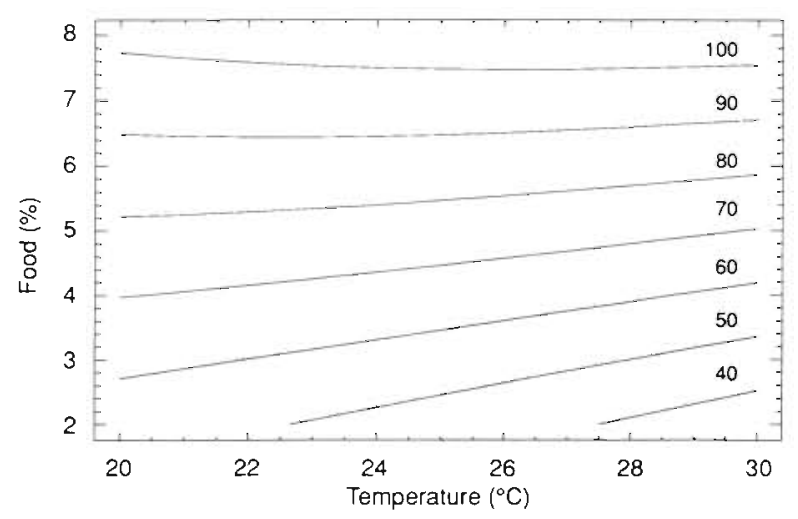

Fig. 3. Pteria sterna. Response under simplified model of condition index (ash free meat dry weight/shell dry weight $\times 100$ ) for temperatures 20 to $30^{\circ} \mathrm{C}$ and food rations 2 to $8 \%$ of meat dry weight

was found in preliminary experiments to be in the range 4.9 to $12.4 \mathrm{l} \mathrm{d}^{-1}$ ind $^{-1}$. Furthermore, for the temperatures and food concentrations used in the present work, the filtration rate was unaffected by both variables. This agrees only in part with many reports in the literature that the feeding activity of filter-feeders is not affected significantly by temperature changes, at least within a specific thermal range (e.g. Wilbur \& Owen 1964, Widdows 1978, Bayne 1985) but is directly related to particle concentrations.

In Mytilus edulis changes in meat and shell increments may be produced by seasonal variations (Hilbish 1986). These changes consist of an uncoupling between tissue and shell growth, which results in a staged growth: tissue increases first and shell later. In Crassostrea virginica such cycles were detected with a duration of between 5 and 7 wk (Ukeles et al. 1984). These examples indicate that the growth of bivalve molluscs may be heterogeneous even under laboratory conditions. In our case, even if meat increase was not measured at regular intervals, such cycles do not appear to exist since shell growth was practically linear in all treatments (Fig. 1).

The growth rates of many bivalves are optimal at temperatures below the highest used in this study. For instance, Pandya (1976) reported that the pearl oyster Pinctada fucata has a higher growth rate at temperatures between 19 and $28^{\circ} \mathrm{C}$ than at 28 to $32^{\circ} \mathrm{C}$, and Chellam (1978) reports similar results for that species. In another example, the growth rates of cultured Tapes semidecussata, $T$ decussata and Mercenaria mercenaria increased between 10 and $25^{\circ} \mathrm{C}$ and decreased at higher temperatures (Laing et al. 1987). Pteria sterna showed a somewhat similar trend as the former examples with respect to meat dry weight, CI and food conversion rate, which were all higher for the intermediate temperature treatment.

The differences in growth between juveniles kept in the laboratory and those reared in Bahia de Los Angeles could be due to different factors. First the diet used in the laboratory was much more abundant than that available under natural conditions, since each individual was fed 1200,2400 and $4800 \mathrm{mg} \mathrm{d}^{-1}$, equivalent to 840,1680 and $3660 \mathrm{mg}$ of organic matter respectively (López-Elías 1990). The few data available on the concentration of total seston and of its organic content in the area, for the period July to November 1986, indicate that the above variables range from maxima of 16.0 and 12.3 to minimum values of 1.4 and $0.3 \mathrm{mg} \mathrm{m}^{-3}$, respectively (Serrano-Guzmán 1992). Taking into consideration that the highest filtration rate we measured for our organisms was only $12.4 \mathrm{l} \mathrm{d}^{-1}$ and that this was not affected by temperature and food concentration, the quantity of seston each individual might have retained in Bahia de Los Angeles was no higher than $2 \mathrm{mg} \mathrm{d}^{-1}$, of which only $1.75 \mathrm{mg}$ was organic matter.

Second, laboratory rations were consumed in a very short time (each half ration usually lasted about $3 \mathrm{~h}$, after which the number of cells in suspension was negligible) and we never noticed the presence of pseudofaeces. Such a high concentration might have affected the efficiency of food assimilation, which is usually low when food is available in excess. In nature, food is not only available (though in lower quantities) on a continuous basis; it is also much more varied, which might also account for the high growth rates of those oysters.

The growth rates observed in the laboratory and in the field are comparable to those of other field studies on Pteria sterna, which range from 2.8 to $7.5 \mathrm{~mm} \mathrm{mo}^{-1}$ (Aguirre-Hinojosa 1987, Araya-Nuñez 1988, SinghCabanillas 1990) compared to 1.6 (lowest) and 4.8 (highest) $\mathrm{mm} \mathrm{mo}^{-1}$ in the laboratory, and 5.8 and $5.2 \mathrm{~mm} \mathrm{mo}^{-1}$ in the field, the latter considering 2 extra winter months (December 1990 and January 1991) when temperatures and food availability are lowest 
(Serrano-Guzmán 1992). A review of the few data available in the literature seems to point to the fact that the wide range of the growth rates reported is due to seasonal differences as well as to the initial size of the organisms. Since growth is strongly influenced by the interaction of food and temperature, it would seem logical to expect that field experiments initiated during the period of spring-summer would result in better growth rates than those carried out in late summer, since more food was available and because temperature was close to the optimum for this species.

\section{CONCLUSIONS}

The analysis of the response surfaces indicates that optimum conditions were not reached in the ranges of our experimental conditions and that growth is mainly under the influence of the interaction between food availability and temperature. The condition index depends principally on food, with a slight negative quadratic effect of the other variable which may explain the higher condition index noted for the lowest temperature.

The fact that optimum conditions were not reached is probably due to food quality or variety, given the tendency of the growth response surface to increase towards temperature and food concentration values which are outside the normal ranges found in the natural environment, in which growth rates are generally higher than those noted in this work.

\section{LITERATURE CITED}

Aguirre-Hinojosa, E. (1987). Anălisis de la fijación, crecimiento y sobrevivencia del mejillón Modiolus capax. durante el desarrollo de una comunidad sobre sustratos artificiales en la Bahía de Los Angeles B.C. M.Sc. thesis, Centro de Investigación Científica y de Educación Superior de Ensenada

Alderdice, D. F. (1972). Factor combinations. Responses of marine poikilotherms to environmental factors acting in concert. In: Kinne, O. (ed.) Marine ecology. Vol. I, Environmental factors, Part 3. Wiley-Interscience, London, p. $1659-1722$

Araya-Nunez, O. (1988). Embryonic and larval development, larval rearing, juvenile growth, gonad maturity and induction of spawning in the west american pearl-oyster Pteria sterna (Gould). M.Sc. thesis, Stockholm University

Ayala-Sánchez, N. E., Michel, R. D. (1980). Relación entre la abundancia, distribución del plancton y el comportamiento de los parámetros hidrológicos en Bahía de Los Angeles, B. C. Memorias del $2^{\circ}$ Simposio Latinoamericano de Acuacultura, México. Secretaría de Pesea, Mexico City, p. $393-446$

Baqueiro, E. (1987). Historia, presente y futuro del cultivo de bivalvos en Mexico. Mem. III Reunión Nal de Malacología y Conquiliología. Soc. Mex de Malacología. Monterrey, p. 469-501
Bayne, B. L. (1973). Physlological changes in Mytilus edulis L. induced by temperature and nutritive stress. $J$. mar. biol. Ass. U.K. 53: 39-58

Bayne, B. L. (1985). Ecological consequences of stress. In: Bayne, B. L. (ed.) The effects of stress and pollution on marine animals. Praeger Scientific Studies, New York, p. $141-135$

Bückle-Ramirez, L. F., Voltolina-Lobina, D., Morales-Guerrero, E., Valenzuela-Buriel, F. (1992). Spat settlement and growth of Pteria sterna (Gould) (Mollusca, Bivalvia) in Bahia de Los Angeles, Baja California, México. Trop. Ecol. 33 (in press)

Chellam, A. (1978). Growth of the pearl oyster Pinctada fucata in the pearl culture farm at Veppalodai. Indian J. Fish. 25: $77-83$

Espina, S. S. (1989). Balance energético de Tivela stultorum (Mollusca, Lamellibranchia). Influencia de factores intrinsecos y extrínsecos. Ph.D. thesis, Universidad Nacional Autónoma de México

Guillard, R. R. L., Ryther, J. H. (1962). Studies on marine planktonic diatoms. I. Cyclotella nana Hustedt, and Detonula confervacea (Cleve) Gran. Can. J. Microbiol. 8: $229-239$

Hahn, K. O. (1989). Handbook of culture of abalone and other marine gastropods. CRC Press, Boca Raton

Hilbish, T. J. (1986). Growth trajectories of shell and soft tissue in bivalves: seasonal variation in Mytilus edulis L. J. exp. mar. Biol. Ecol. 96: 103-113

Laing, I., Utting, S. D., Kilada, R. W. S. (1987). Interactive effect of diet and temperature on growth of juvenile clams. J. exp. mar. Biol. Ecol. 113: 23-38

López-Elías, J. A. (1990). Cultivos semicontinuos de cuatro especies de microalgas con medios simplificados: evaluación de técnicas analíticas y de producción. M.Sc. thesis, Centro de Investigación Científica y de Educación Superior de Ensenada

Lough, R. G., Gonor, J. J. (1973a). A response surface approach to the combined effect of temperature and salinity on the larval development of Adula californiensis (Pelecypoda: Mytilidae). I. Survival and growth of three and fifteen-day old larvae. Mar. Biol. 22: 241-250

Lough, R. G., Gonor, J. J. (1973b). A response surface approach to the combined effects of temperature and salinity on the larval development of Adula californiensis (Pelecypoda: Mytilidae). II. Long-term larval survival and growth in relation to respiration. Mar. Biol. 22: 295-305

Lucas, A., Beninger, P. G. (1985). The use of physiological condition indexes in marine bivalve aquaculture. Aquaculture 44: $187-200$

Pandya, S. A. (1976). Influence of temperature on growth ring in the pearl oyster Pinctada fucata (Gould) of the Gulf of Kutch. Indian J. mar. Sci. 5: 249-251

Serrano-Guzmán, S. J. (1992). Dispersión de larvas de bivalvos y seston total por corrientes costeras, dentro del sistema Bahía de los Angeles, B. C. México. M.Sc. thesis, Centro de Investigación Cientifica y de Educación Superior de Ensenada

Schnute, J., McKinnell, S. (1984). A biologically meaningful approach to response surface analysis. Can. J. Fish. Aquat. Sci. 41. 936-953

Singh-Cabanillas, J. (1990). Crecimiento y supervivencia de la concha nácar Ptena sterna (Gould, 1851) en la Bahia de la Paz, B. C. S. Abstracts IV Mexican Congress of Aquaculture. AMAC '90, Hermosillo, p. 82

Steel, R. G. D., Torrie, J. H. (1988). Bioestadística. Principios y procedimientos, 2 nd edn. (Spanish version). McGraw-Hill, Mexico 
Ukeles, R., Wikfors, G. H., Twarog, J. W. (1984). Relative growth rate cycles in Crassostrea viginica (Gmelin) fed five algal diets. J. Shellfish Res. 4: 155-159

Voltolina-Lobina, D., Trujillo-Valle, M. de L., GonzálezLeonardo, M. I. (1991). La colección de cepas de microalgas del Departamento de Acuicultura del C.I.C.E.S.E. Comunicaciones Académicas. CTACT-9101 Centro de Investigación Científica y de Educación Superior de Ensenada, Ensenada

This article was submitted to the editor
Widdows, J. (1978). Combined effects of body size, food concentration and season on the physiology of Mytilus edulis. J. mar. biol. Ass. U.K. 58: 109-124

Wilbur, K. M., Owen, G. (1964). Growth. In: Wilbur, K. M., Yonge, C. M. (eds.) Physiology of Mollusca, Vol. 1. Academic Press, New York, p. 211-242

Zar, J. H. (1974). Biostatistical analysis. Prentice-Hall, Inc., Englewood Cliffs

Manuscript first received: May 25, 1992

Revised version accepted: October 23, 1992 